\title{
Determinants Of Savings In The SADC Region: The Role Of Foreign Capital And Financial Development
}

Forget Mingiri Kapingura, University of Fort Hare, South Africa Sylvanus Ikhide, Ph.D., University of Stellenbosch Business School, South Africa Asrat Tsegaye, Ph.D., University of Fort Hare, South Africa

\begin{abstract}
${ }^{1}$
The study examines the determinants of savings in the SADC region, mainly focusing on the roles played by external financial flows and financial development in mobilising domestic savings utilising panel cointegration method and the Dynamic ordinary Least Squares (DOLS) approach from 1980 to 2009. Following the review of literature, the empirical model adopted established that there is a long-run relationship between the variables of interest. The results indicate that income, proxied with GDP, financial sector development and foreign capital have a positive relationship with savings. The results also suggest that financial sector development has played a very important role in influencing savings in the region. However on the other hand the results indicate that interest rate and dependency ratio have influenced savings negatively. The empirical results support the hypothesis that foreign savings bridges the gap between domestic demand and supply of finance in the SADC countries. There is need to attract more foreign capital given that it compliments domestic savings. At the same time policies aimed at financial deepening should still be pursued to further deepen the financial system in the SADC countries to further enhance savings.
\end{abstract}

Keywords: Gross Domestic Savings; SADC; Panel Cointegration

\section{INTRODUCTION AND BACKGROUND}

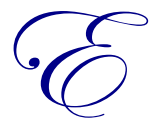

stablishing the factors that determine the accumulation of savings is an area which has attracted attention at both the academic and policy discourse. This is acceptable given the importance of savings to a country. A number of studies (Chowdhury, 2001; Quartey, 2005; Odhiambo, 2008; Ang, 2010; Adenutsi, 2010) indicates that savings which are generated in the domestic economy provides the wherewithal for the financing of domestic fixed capital formation, which, in turn, affects employment and economic growth.

There are additional studies which indicate that when a country has a high level of savings it will help in reducing the current account deficit which is a common scenario in SADC countries. In addion, Luüs (2007) argue that in the event that there are not enough savings, the country is likely to further widen the current account deficit or it may fail to maximize on investments in the domestic economy.

The need to enhance domestic savings arises because external finance is argued to have been ineffective in reducing credit constraints common in many developing countries. However, lack of appropriate financial systems which are able to efficiently pool savings of households to make them available to borrowers has been suggested to be one of the contributing factors Liu and Woo, 1994; Granville and Mallick, 2004; Odhiambo, 2008; Ang, 2010).

\footnotetext{
${ }^{1}$ First version of the paper was presented at the 2015 International Business Conference, the Clute Institute, San Juan, Puerto Rico, March 22 26. 
On the other hand, it is important to note also that there are recent studies such as (Boswarth and Collins 1999; Ahmad and Ahmed 2002; Waheed 2004; Bashier et al 2007; Kumar 2007; Okafor et al 2009; Delwar 2012; Temitope 2014) which have emerged suggesting that relying on foreign capital may be another reason why countries fail to mobilise savings. The majority of these studies suggest that an increase in foreign capital may displace domestic saving and that will hamper economic growth in less developed countries.

This is also consistent with Shaheen et al (2013) who argues that in a country where the savings rate is very low, foreign capital may act as a major determinant of economic growth as well as consumption patterns. The author also mentions that FDI may have a negative impact on the recipient economy, in that it may create macroeconomic imbalances such as high inflation rates, rapid monetary expansion, widened current account deficits as well as substituting domestic savings.

In the SADC region it is interesting to note that national savings as a percentage of GDP stood at $14.9 \%$, a figure which is lower than the 2010 of $15.5 \%$. The lower savings rates impacted negatively on investment which fell from 22.2 percent to 21.3 percent during the same period. This becomes worrisome given that the region still lags behind its target of 30 percent level of investment.

It is also interesting to note that the majority of countries in the SADC region rely mostly on commodity prices to support the growth needs in the respective countries. However this channel is highly vulnerable to a downturn as witnessed during the Global financial crisis when export revenues due to the decline in the world demand for minerals and fossil resources.

In addition, the SADC protocol state that the countries rely much on foreign capital to finance their investment needs. A cursory analysis on the contribution of FDI to Gross capital formation in some of the SADC countries is worrisome. Countries such as Angola have about $109 \%$ of their investment needs being supported by FDI. The same applies to Seychelles at $76.7 \%$, Mozambique at $32.1 \%$, Zambia at $26.3 \%$ and Madagascar at $26 \%$. Given that there is a reversal of capital, these countries will be affected greatly.

This suggests the need to establish the determinants of savings in these countries as there are quite a number of advantages associated with savings as compared to foreign capital. Luüs (2007) also shows that higher saving has the central virtue of providing the country with options, not merely if the country's economic strength continues as the expectation of economic agents, but also if it does not. Given that foreign capital plays a very important role as far as investment activities as well as growth in the SADC region, it also becomes important to establish its impact on domestic savings given that there are mixed views on how it influences savings in a domestic country. The study will also seek to establish the role played by financial sector development in influencing savings in the region.

The study seeks to establish a number of objectives. Firstly, the study seeks to establish the determinants of Savings in the SADC region; secondly to establishing the extent to which foreign capital compliments or substitutes domestic savings in the SADC region and lastly based on empirical results articulate policy recommendations based on the results of the study. It is interesting to note that the majority of the studies which have examined the determinants of savings have relied much on conventional variables, not taking into account the impact of external financial flows which a number of recent studies suggest that it might have a significant influence on savings as well as economic growth in the SADC region. This study thus incorporate the role of financial development and the extent to which external finance impacts on savings in the SADC region.

The study is made of five sections. Following section one, section two looks at the available literature on the subject. Section three provides the methodology and discussion of the data to be used in the study. Section four provides a discussion of the results of the models estimated in section three. Section five provides the conclusion and recommendations of the study. 


\section{REVIEW OF LITERATURE AND THEORETICAL FRAMEWORK}

The available studies on the determinants of savings constitute studies which have been done both at country level and cross country. Also it is interesting to note that the majority of the studies have employed aggregate saving data as compared to using disaggregated data. This is justified as it allows comparisons to be made between countries.

A number of authors have focused on establishing a long-term relationship between savings and its determinants. These authors have relied on methods which seeks to establish a long-term relationship using Engle Granger, Johansen cointegration test and the Autoregressive Distributed Lag (ARDL) model (Chowdhury, 2001; Quartey, 2005; Odhiambo, 2008; Ang, 2010; Adenutsi, 2010;).

Starting with the work of Quartey (2005), the author analysed the impact of financial development on savings and poverty in Ghana for the period 1970 to 2001 employing the Johansen cointegration test and Granger causality. Empirical results revealed that there is no evidence of a causal relationship between financial sector development and savings in Ghana. This was attributed to the under-development of the financial sector, resulting in it failing to play its roll of mobilizing savings. These results implied that authorities should focus at policies which are aimed at improving the financial sector. However, these results were contrary to Adenutsi (2010) who employed the Structural Vector Autoregressive (SVAR) model. The author argues the model ameliorates the analysis of various economic issues by eliminating the problem of identification of the contemporaneous and dynamic relationships between a set of macroeconomic variables and the appropriate policy instruments. The results revealed that financial sector development has enhanced the performance of commercial banks by way of savings mobilisation but adversely impacted on the long-run economic performance directly. This also implied that policy measures aimed at further enhancing financial deepening should be pursued. This result is consistent with Asamoah (2008) for the same country.

Odhiambo (2008) also employed the Johansen cointegration test in Tanzania for the period 1968 to 2001 and established that financial deepening positively influences the level of domestic savings. Again this implies that policies aimed at promoting financial sector development should be pursued. However on a study of Kenya the author using the tri-variate Granger causality did not found a causal relationship from financial development to savings. To the contrary, the author established that savings promote financial sector development.

There are studies which have also employed the ARDL model. This model is considered robust taking into account that it is able to test for the existence of a long-run relationship regardless of whether the underlying time series are individually I(1) or I(0). Of these studies, Ang (2010) analysed the impact of the financial system on savings in Malaysia for the period 1960 to 2007. Empirical results revealed that financial deepening impacts positively on savings. However, on the other hand it was found that the development of the insurance markets, and liberalization of the financial system tend to reduce the level of savings in Malaysia. This implies that development of the financial system which may increase borrowing patterns will likely boost consumption at the expense of savings. Employing the same model, Khan and Hye (2010) carried out a similar study in Pakistan for the period 1988 to 2008. The authors found that financial sector development was found to have negatively affected the level of savings both in the short-run and long-run. However, employing the same model in UK, Granville and Mallick (2002) found that financial sector development promotes savings and hence economic growth.

On a study in Nigeria however Nwachuku (2009) employed the Error Correction Model to establish the impact of financial development on savings for the period 1970 to 2007. The author argues that this kind of model minimises the possibility of estimating spurious relations, while at the same time retaining long-run information. Empirical results revealed that the degree of financial depth was found to have a negative and insignificant impact on saving behaviour in Nigeria. This is consistent with Chowdhury (2001) in the case of Bangladesh. The author found that financial sector reform was found to be negatively related to savings. However the author attributed this to the government involvement in bank management. It is argued that loans were extended to individuals with high credit risk leading to high default rate, thus discouraging savers from trusting their monies with such institutions. This implies therefore that government involvement may result in market imperfections. There should be minimal to none government involvement in the financial sector. The government should be restricted to the regulation aspects. 
At cross country level Mavrotas and Kelly (2008) carried out a study on 17 African countries for the period 1972 to 1994 employing the Pedroni panel cointegration test which the authors argue that it allows to investigate heterogeneous panels, in which heterogeneous slope coefficients, fixed effects and individual specific deterministic trends are permitted. However results were inconclusive even though a positive relationship was established in many of the countries. The authors argue that as much as strengthening the weak financial systems in Africa is crucial, careful consideration should be given to channels through which the financial system can improve the level of savings. Thus the authors argue that much significance should be given to improving the overall macroeconomic stability, proper regulation and supervision of local banks as well as the regulatory environment for micro-finance institutions to be appropriate policy directions along with encouraging the provision of savings facilities.

In the same vein Sahoo and Dash (2013) carried out a study on South Asia for the period 1975 to 1991 and 1992 to 2010 employing the panel cointegration test. Empirical results revealed that there is a positive association between the financial sector development and the savings rate. Thus the authors argue that development of the financial system will result in the mobilisation of savings.

There are other studies which have examined the impact of liberalization on savings. These studies include Bandiera, Caprio, Honohan and Schiantararelli (2000); Bayoumi (1993); Jappelli and Pagano (1994); Koskela, Loikkanen and Viren (1992); Loayza, Schmidt-Hebbel and Serven (2000) and Reinhart and Tokatlidis (2001) amongst others. However there is no consensus as regards the impact of liberalization on savings mobilization.

Starting with Koskela et al (1992), the authors reviewed the interaction between prices of owner occupied houses and the household saving ratio in Finland for the periods 1970s and 1980s. The authors noted that the volatility of house prices could be traced to major changes which were taking place in the financial markets. The authors found that financial market conditions which were measured by household's indebtedness rate, after tax rate of return on housing and the thinness of rental markets had a positive effect on household prices. However, household savings were negatively affected by the rate of change of house prices, though affected positively by the after tax nominal interest rate. The study therefore imply that financial conditions, together with the liberalization which took place in Finland in the 1980s contributed immensely to the decline in household saving ratio.

In the same vein, Bayoumi (1993) examined the impact of financial deregulation on personal savings, on 11 regions of the United Kingdom utilising the overlapping generations' framework. The author noted that financial deregulation led to a decrease in saving rates in the UK. The author also noted that savings became more sensitive to wealth, real interest rate and current income. The author concluded that about $2.25 \%$ decline in personal savings at that time was attributed to financial deregulation alone. This is consistent with Jappelli and Pagano (1994) who investigated the role of capital markets imperfections on savings and growth for OECD countries using a panel study for the period from 1960 to 1987. The authors employed the simple overlapping generations' model in their analysis. Empirical results revealed that liquidity constrains on households has the capability of raising the savings rate. The authors concluded that financial deregulation which took place in the 1980s contributed to the decline in national savings in the OECD countries. The authors therefore expressed concern on the implications of further liberalization on welfare within the European Union.

Loayza et al (2000) examined the factors that drives private savings on a number of countries, using cross sectional time series data. Empirical results suggested that financial liberalization does not support private savings. It was found that the real interest rate has a negative impact on the savings rate. In greater part, the income effect was more than the substitution effect as well as the human wealth effect. The authors noted that a $1 \%$ increase in real interest rate, would result in a $0.25 \%$ decline in private savings in the short-run. This implies that liberalization of the financial sector should be taken with caution.

There are other studies which have established mixed results on the impact of liberalization on the savings rate. Bandiera et al (2000) carried out a study on the impact of liberalization on savings for different countries which include Chile, Ghana, Indonesia, Korea, Malaysia, Mexico, Turkey and Zimbabwe for the period 1970 to 1994 . The authors created an index of financial liberalization which constituted interest rates, direct credit, reserve requirements, bank ownership, security markets deregulation, prudential regulation and capital account liberalization. The empirical results revealed that there is no positive effect of the real interest rate on savings for all 
the countries. In the majority of the countries, it was found that the relationship is negative and significant for countries such as Ghana and Indonesia. The index presented mixed results with countries such as Turkey and Ghana presenting a positive and significant relationship, whilst, other countries such as Korea and Mexico exhibiting a negative and significant relationship. The authors also estimated the Augmented Euler equations to examine the impact of liberalization on liquidity constrains. Empirical results could not confirm if financial liberalization removes constrains on access to credit. It was therefore concluded that the interest rate has no significant effect on savings. On the other hand, the effects of liberalization on savings were mixed. Again this implies that regulation of the financial system should be done in a cautious manner. Its success in mobilizing savings depends on whether the majority of people are net savers or consumers.

On another study Reinhart and Tokatlids (2001) on a study involving 50 countries noted that financial liberalization resulted in higher interest rates, lower investment, and a higher level of foreign direct investment and a high rate of gross capital flows. The authors argue that liberalization results in financial deepening mostly in developed countries. However in low income countries the benefits of liberalization were not identified. Regarding the impact of liberalization on savings, the results were mixed with some of the countries indicating that savings increased after liberalization, whilst in the majority of the countries it was to the contrary. The authors therefore concluded that financial sector liberalization may result in a country having access to international capital markets, though this was not supported by low income countries.

There are other studies which have just focused on analysing the impact of foreign capital on savings. Of these studies, Boswarth and Collins (1999) studied the implications of both aggregated financial flows and disaggregated flows (FDI, portfolio investment and loans) on domestic investment, saving and current account for 58 developing countries for the period 1978 - 1995. The authors employed OLS fixed effect and instrumental variables approaches. The result for aggregate data shows insignificant relationship between foreign capital inflows and savings. However, when the foreign capital inflows are disaggregated they have different implications on the savings. There is a significant positive effect of FDI, negative effective loans and little negative effect of portfolio investment.

Delwar (2012) studied the negative impact of remittances inflow on domestic saving. The author argues that remittances are usually used for consumption due to trend in emigrants to spend their savings on consumer goods and emigrants feels the lack of satisfying investment opportunities offered to them, as well as lack of organised capital markets that can be absorb these funds. For these reason it has been argued that there is a negative link between emigrant remittances and domestic savings. According to macro-economic theory remittances have negative impact on saving through negative impact on interest rates.

Ahmad and Ahmed (2002) employed co-integration and error correction models to examine the impact of foreign capital inflows and domestic saving in Pakistan for the period 1972 to 2002.The authors suggest that the Unrestricted Error Correction Model found short run significance inverse relationship between domestic saving and foreign inflows but Short-Run Dynamic Engle-Granger procedure found insignificant inverse relationship between foreign capital inflow and domestic saving. Thus the authors argued that external capital flows permitted a relaxation in saving effort and encourage an increase in consumption and therefore, external flows may particularly impedes the public saving as well as private savings.

Waheed (2004) conducted evaluation of selected studies on foreign capital inflows and savings which mostly find the negative relationship between the foreign capital inflow and the domestic savings. However, the author concluded that the results of previous studies are largely controversial mainly due to methodological problems or data limitations.

Bashier et al (2007) studied the causal relationship between foreign direct investment and net domestic savings in Jordan for the period 1971-2005 employing the Johansen cointegration test and error correction model. The authors emphasised that there is a positive causal relationship between FDI and net domestic saving. The estimation result of the error correction model shows that the causal relationship run from FDI to net domestic saving, not from net domestic saving to FDI. 
Kumar (2007) investigated the impact of foreign direct investment on saving and investment and found that foreign direct investment has a significant effect on both savings and investment. The author indicates that FDI to GDP leads to an increase of a half percentage point in the fourths percentage point in domestic savings. Thus the author stress that FDI actually crowds in domestic investment and having positive impact on savings.

Okafor et al (2009) determined the potential causality between foreign debt and savings within the context of developing countries, sub-Saharan Africa and Latin America for the period of 1975 to 2004. The results showed that foreign debts impacts negatively on gross domestic savings, especially in the long run. The sensitivity analysis suggest that there is indeed a strong magnification effect - a 1 percent increase in foreign debt share may result in as much as a 7.8 percent reduction in savings efforts and GDP per capita positively related with gross domestic saving.

Temitope (2014) studied the effects of foreign resources inflow and savings on the economic growth of South Africa by using Vector autoregressive analysis (VAR)and the impulse -response function (IRF) over the period of 1975 to 2011. The results from the VAR Granger test of causality showed that domestic savings lead economic growth, while economic growth leads investment. This result of the IRF also showed that while increased domestic savings is important to improve the level of economic growth in South Africa, it also leads FDI. This means that the economic environment needs to be suitable in order to attract foreign investments.

The empirical studies reveals mixed results. From the review it is evident that developing a strong financial system is very important to mobilise domestic savings. However it is not an end in itself, but there are many factors to take into account, like macroeconomic stability, demographic factor amongst others which also determine the savings rate. The review of literature has also shown that liberalization of the financial system may not result in the accumulation of savings as it depends on the income effect and the substitution effect. Also the review has indicated that financial development may result in an increase in borrowing which may be a detriment to savings. The review also suggest that there are mixed views regarding the impact of foreign capital. There are some studies which argue that foreign capital displaces domestic savings, whilst on the other hand other studies argue that it complements domestic savings.

\section{METHODOLOGY AND DATA}

In analysing the determinants of savings in the SADC region the study will adopt the life-cycle/ permanent income hypothesis developed by hall (1978). This approach takes into account both the lifecycle and permanent income variables. These frameworks were discussed in the theoretical literature section.

\section{Model Specification}

The model to be utilised in the study is borrowed from Kelly and Mavrotas (2008), Yeye (2011) and Bosede (2013). The model can be specified as follows:

$$
Z_{i t}=\alpha_{i}+\beta X_{i t}+\mu_{i}+\varepsilon_{i t}
$$

Where $Z_{i t}$ is the gross domestic savings it representing each of the variables across the countries, $\alpha$ is the country specific effect. The constant in this regard represents non-measurable net effect of omitted time invariant variables such as political instability and persistence which is specific to each country. The $X_{i t}$ is the vector of saving determinants which are the explanatory variables to be employed in the study across the countries over a period of time. $\mu_{i}$ and $\varepsilon_{i t}$ are the error term in the equation.

The multivariate equation can be stated as follows:

$$
G D S_{i t}=\beta_{0}+\beta_{1} Y_{i t}+\beta_{2} i_{i t}+\beta_{3} \pi_{i t}+\beta_{4} F D_{i t}+\beta_{5} F E F_{i t}+\beta_{6} D R_{i t}+\varepsilon_{i t}
$$

Where $\boldsymbol{i t}$, is the time period in country $k$, GDS, is Gross Domestic Saving rate, $\mathbf{Y}$, is the Growth Rate of Gross Domestic Product, $\boldsymbol{i}$, is the interest rate, $\boldsymbol{\pi}$, is the inflation rate, FD, is a measure of financial sector development, 
FEF, is a measure of Foreign External Finance, DR, is the overall age-dependency ratio, defined as the ratio of nonworking age population and $\varepsilon$ is the disturbance term that captures the unobservable effect and it is assumed to be white noise. These variables will be defined in detail in the next section.

\section{Definition of Variables and Apriori Expectations}

The Keynesian view on savings postulates that savings depends on income, such that an increase in income is likely to result in an increase in savings. Therefore, a positive relationship between savings and income will be expected. This is supported by other prior studies such as Masson et al (1998), Loayza (2000) and Ang (2009). In this study income is captured by the growth rate of GDP. This is again consistent with Yaya (2011) and Bosede (2013). DR measures the dependency rate. As mentioned earlier, this is defined as the ratio of non-working age population, that is the population either younger than 15 or older than 65 years of age. The LCM theory postulates that dependency encourages dissaving, therefore, a negative relationship between age and savings is expected. This is supported by Loayza et al (2000). Financial development (FD) is measured by a number of variables to obtain robust results. It will be measured by bank credit to the private sector as a ratio of GDP and Money supply as measured by $M 2$ as a percentage of GDP. Though Ang (2010) argues that the a priori sign of these measures cannot be determined prior to empirical investigation, in our case a positive relationship between the measures of financial sector development and savings is expected. There are two strands of theory which explains the impact of financial development on savings. One strand of theory postulates that development of the financial sector improves resource mobilisation and hence savings (Sahoo and Dash, 2013). On the other hand it is argued that financial development can make access to finance to be easy and hence boost consumption (Nair, 2006). Apart from obtaining robust results by using three measures of financial development, there is no consensus regarding the best measure of financial development in the literature (Ang, 2008, Adenutsi, 2010). FER represents External Financial Flows. It will be measured by Foreign Direct Investment and Cross Boarder Banking. There is no consensus regarding the impact of foreign external financial flows on savings. There are studies such as Kumar (2007) and Bashier et al (2007) which argues that external financial flows augment domestic savings, whilst Ahmed and Ahmed (2002) and Waheed (2004) argue that foreign finance has a negative impact on savings. The impact of external finance on savings will therefore be determined empirically. $I$ is the rate of interest, according to the Keynesian theory, an increase in interest will result in more savings as people postpone consumption in the current period to the future. The relationship between savings and savings is highly dependent on the substitution and income effects, and also whether individuals are net savers or net borrowers. If people are net borrowers, an increase in the interest rate may cause the income effect to dominate the substitution effect. In this case, savings will fall, rather than increase. The Keynesian view here breaks down. However, if individuals are net savers, an increase in the interest rate will favour future relative to current consumption. The substitution effect is large, and savers will increase.

The data for FDI and Cross Boarder Bank flows utilised in the study was obtained from the World Bank' Global Development Financial data base. Data for GDP, inflation, interest rate, Dependency ratio, Gross Domestic Savings was collected from the World Bank's World development Indicators.

\section{Estimation Techniques}

The study employs the panel integration and cointegration tests for a group of 15 SADC countries to examine the long-run determinants of savings in the SADC region. The use of panel unit root and cointegration tests allows for the determination of the long-run structure of savings in a dynamic setting. This avoids the problem of using the statistic cointegrating testing which is common (Kelly and Mavrotas, 2008). Also the panel approach solves for the problem of sensitivity of cointegration tests to low-powered stationarity tests which is common in the case of time-series analysis. Another important point is that panel data techniques allows for heterogeneity in coefficients and dynamics across countries.

\section{Testing for Stationarity in Panel Data}

As with standard cointegration tests, it is of great importance to establish the time series properties of the data to ensure that incorrect inference are not made. The study will employ the tests discussed in chapter 4 . These 
methods will be discussed again briefly in this section. For panel unit root tests the study will employ the Levin and Lin (LL) test, Im Pesaran and Shin (IPS) test and the Maddala and Wu (MW) test.

\section{The Levin and Lin (LL) Test}

This test was originally developed by Levin and Lin (2002). The test is an extension of the DF test. The model is of the following form:

$$
\Delta Y_{i, t}=a_{i}+\rho Y_{i, t-1}+\sum_{k=1}^{n} \phi_{k} \Delta Y_{i, t-k}+\delta_{i} t+\theta_{t}+u_{i t}
$$

Asteriou and Hall state that the model allow for two-way fixed effects, one coming from $a_{i}$ and the other from $\theta_{t}$. Therefore, both unit-specific fixed effects and unit specific time effects are included. The unit-specific fixed effects allow for heterogeneity since the lagged $Y_{i}$ is restricted to being homogenous across all units of the panel.

\section{The Im, Pesaran and Shin (IPS) Test}

Im, Pesaran and Shin (2002) extended the LL test taking into account heterogeneity on the coefficient of the $Y_{i, t-I}$ variable and proposing a procedure which relies on the average of the individual unit-root test statistics. The IPS test provides separate estimations for each $i$ section, allowing different specifications of the parametric values, the residual variance and the lag lengths. The model is given as:

$$
\Delta Y_{i, t}=a_{i}+\rho_{i} Y_{i, t-1}+\sum_{k=1}^{n} \phi_{i k} \Delta Y_{i, t-k}+\delta_{i} t+u_{i t}
$$

\section{The Maddala and Wu (MW) Test}

Maddala and $\mathrm{Wu}(1999)$ came up with a model that tries to take into account the shortcomings of the other methods discussed. The authors are in line with the assumption that a heterogeneous alternative is preferred. However they argue regarding the use of the average ADF-statistics saying it is not the effective way of evaluating stationarity. Assuming $N$ unit root tests, the MW test takes the following form:

$$
\Pi=-2 \sum_{i=1}^{N} \ln \pi i
$$

where $\pi$ is the probability limit values from regular DF or ADF unit-root tests for each cross-section $i$. Since $-2 \ln \pi_{i}$ has a $\chi^{2}$ distribution with 2 degrees of freedom. The $\prod$ statistic will follow $\chi^{2}$ distribution with $2 \mathrm{~N}$ degrees of freedom as $T_{i} \rightarrow \infty$ for finite N. In considering the dependence between cross-sections, the authors proposed obtaining the $\pi_{i}$ values using bootstrapping as the correlations between groups can induce significant size distortions for the test.

The panel to be estimated in the study is of an unbalanced nature, therefore two methods, the LL test and the MW will be considered. The two tests will be considered to obtain robust results. The result of the MW will take precedence where there is conflict.

\section{Panel Cointegration Test}

There are several methods which have been suggested to conduct panel cointegration tests. Asteriou and Hall (2011) state that the best known methods of panel cointegration are based on the Engle and Granger (EG) cointegration relationship. The EG procedure state that if two variables are cointegrated, there exists an error 
correcting formulation of the dynamic model. The study will focus on establishing if there is a long-term relationship between the variables, not necessarily how many cointegrating equations. In this section, the Kao test and Pedron tests discussed.

\section{The Kao Test}

According to the work of Baltagi and Kao (2000) and Asteriou and Hall (2011), the Kao test presents two types of cointegration tests in panel data based on the Dickey Fuller (DF) and the Augmented Dickey Fuller (ADF). Given a simplified model:

$$
Y_{i t}=\alpha_{i}+\beta X_{i t}+\hat{u}_{i t}
$$

The DF residual- based cointegration test according to the Kao can be applied to equation (5.6) as:

$$
\hat{u}_{i t}=\rho e_{i t}+v_{i t}
$$

where $\hat{u}_{i t}$ is the estimated residual from equation (5.7). Baltagi and Kao (2000) shows that in order to test the null hypothesis of no cointegration, the null can be written as $H_{0}: \rho=1$.

However, Kao's panel cointegration test though is applauded on its ability to impose homogenous cointegrating vectors and AR coefficients, it has been criticised for its failure not to allow for multiple exogenous variables in the cointegrating vector. Another flaw with the method is its inability of not addressing the issue of identifying the cointegrating vectors and the cases where more than one cointegrating vector exists.

\section{The Pedron Tests}

Pedron $(1997,1999,2000)$ proposed several tests for cointegration in panel data models that allows for considerable heterogeneity. Asteriou and Hall (2011) also shows that the Pedron's approach differs from the McCoskey and Kao in assuming trends for the cross-sections and in considering as the null hypothesis that of no cointegration. The Pedron's tests has been applauded for allowing multiple $(\mathrm{m}=1,2, \ldots \ldots \ldots, \mathrm{M})$ regressors, for the cointegration vector to vary across different sections of the panel, and for heterogeneity in the errors across crosssections units. According to Asteriou and Hall (2011), the Pedroni regression model is of the following form:

$$
Y_{i, t}=\alpha_{i}+\delta_{t}+\sum_{m=1}^{M} \beta_{m i} X_{m i, t}+u_{i, t}
$$

Baltagi and Kao (2000) states that Pedron's tests can be classified into two categories, the first four are similar to the two tests discussed above, and involve averaging test statistics for cointegration in the time series across-sections. The second set groups the statistics such that instead of averaging across statistics, the average is done in pieces so that the limiting distributions are based on limits of piecewise numerator and denominator terms.

Kelly and Mavrotas (2008) argue that the size distortions are minor and power is high for all statistics when the time span is long. However, in the case of shorter panels, the evidence is more varied. In the event that there is conflict amongst the statistics, Pedron (1997) argue that the group adf statistic and panel adf statistic generally performs best. 


\section{Dynamic Ordinary Least Square Method}

Having established the presence of cointegration in the model, the next step will be to analyse the long-run relationship between the variables of interest. The study will employ the Dynamic Ordinary Least Square method (DOLS) in the analysis.

Hawdon and Ahmed (1997) argue that the DOLS approach improves on OLS by coping with small sample and dynamic sources of bias. The authors also argue that the method is a robust single equation approach which corrects for regressors endogeneity by the inclusion of leads and lags of first differences of the regressors, and for serially correlated errors by a GLS procedure. In addition the method has the same asymptotic optimality properties as the Johansen distribution.

In addition, Muhammad and Stern (2001) also argue that DOLS as opposed to many other estimators does not require all the individual series in a long-term relationship to be integrated of order one, as it is also applicable to systems involving variables of differing orders of integration. In the case of I(1) series, the DOLS technique involves regressing one variable on the contemporaneous levels of the other variables and on the leads and lags of their first differences and a constant term. written as:

Assuming that the individual variables of the model are all I(1), the DOLS estimating equation can be

$$
\begin{aligned}
& G D S_{i t}=\beta_{0}+\beta_{I} Y_{i t}+\beta_{2} i_{i t}+\beta_{3} \pi_{i t}+\beta_{4} F D_{i t}+\beta_{5} F E F_{i t}+\beta_{6} D R_{i t}+\beta_{7} C A_{i t}+\ldots \ldots \\
& \ldots+\sum_{s=-p}^{p} \beta_{s} \Delta Y_{i t-s}+\sum_{s=-p}^{p} \delta_{s} \Delta i_{i t-s}+\sum_{s=-p}^{p} \chi_{s} \Delta \pi_{i t-s}+\sum_{s=-p}^{p} \varphi_{s} \Delta F D_{i t-s}+\sum_{s=-p}^{p} \alpha_{s} \Delta F E F_{i t-s}+\sum_{s=-p}^{p} \theta_{s} \Delta D R_{i t-s} \ldots(5.9) \\
& \ldots .+\mu_{i t}
\end{aligned}
$$

Equation 7.32 is the extended version of a Dynamic OLS (DOLS) model which was used to estimate the long-run relationship in cointegrated models.

\section{Presentation and Discussion of the Empirical Results}

The empirical analysis began with the analysis of the stationarity of the variables. As mentioned earlier, three tests were conducted for robust results and the results are reported in table 6.1 and 6.2. The requirement is to prove that all the variables to be employed in the study are non-stationary at level series to be able to check for cointegration.

Table 4.1. Unit Root tests: Level Series

\begin{tabular}{lrrrrrrrrr}
\hline \multicolumn{1}{c}{ Panel } & \multirow{2}{*}{ GDS } & GDP & $\begin{array}{c}\text { Interest } \\
\text { rate }\end{array}$ & Inflation & DCP & M2 & FDI & CBB & DR \\
\hline LL & -1.7143 & -1.2853 & -0.3136 & -0.7572 & 1.49033 & 1.0283 & -0.7868 & 2.7009 & -0.5005 \\
IPS & -1.9303 & -0.7302 & -0.4866 & -0.5127 & 2.30491 & 1.3185 & -0.9540 & -0.4215 & -2.4030 \\
MW & -2.2931 & -0.5390 & -1.4557 & -0.9907 & 2.5572 & 2.1987 & -0.9983 & 0.6683 & 0.92879 \\
\hline
\end{tabular}

Notes:

(1) The t-statistics for each test is reported.

(2) The Null hypothesis: Variable has a unit root.

(3) The null hypothesis of stationarity is tested. *,**,*** indicates the parameters that are significant at $10 \%, 5 \%, 1 \%$ probability respectively.

Source: Author's calculations

The results in table 4.1 indicate that all the variables to be employed in the study are non-stationary at their level series as reported by the different tests. The variables were analysed for unit root at first difference and the results are reported in table 4.2. 
Table 4.2. Unit Root test: First Difference Series

\begin{tabular}{|c|c|c|c|c|c|c|c|c|c|}
\hline Panel & GDS & GDP & $\begin{array}{c}\text { Interest } \\
\text { rate }\end{array}$ & Inflation & DCP & M2 & FDI & CBB & DR \\
\hline $\mathbf{L L}$ & $-7.581 * * *$ & $-11.41 * * *$ & $-9.353 * * *$ & $-10.29 * * *$ & $-5.002 * * *$ & $-6.930 * * *$ & $-15.08 * * *$ & $-4.080 * * *$ & $-7.788 * * *$ \\
\hline IPS & $-10.77 * * *$ & $-16.39 * * *$ & $-11.68 * * *$ & $-15.58 * * *$ & $-7.539 * * *$ & $-7.799 * * *$ & $-15.74 * * *$ & $-7.636 * * *$ & $-10.08 * * *$ \\
\hline MW & $-15.861 * * *$ & $-16.47 * * *$ & $-14.38 * * *$ & $-17.76 * * *$ & $-12.55 * * *$ & $-11.04 * * *$ & $-17.81 * * *$ & $-12.26 * * *$ & $-3.110 * * *$ \\
\hline \multicolumn{10}{|l|}{ Notes: } \\
\hline (1) & \multicolumn{9}{|c|}{ The t-statistics for each test is reported. } \\
\hline (2) & \multicolumn{9}{|c|}{ The Null hypothesis: Variable has a unit root. } \\
\hline (3) & \multicolumn{9}{|c|}{$\begin{array}{l}\text { The null hypothesis of stationarity is tested. } * * *, * * * \text { indicates the parameters that are significant at } 10 \%, 5 \%, 1 \% \text { probability } \\
\text { respectively. }\end{array}$} \\
\hline Sout & Author's calcu & & & & & & & & \\
\hline
\end{tabular}

In this case just like in the previous test, the appropriate null hypothesis is the stationarity of the variable. All tests employed indicate that all variables are stationary at $5 \%$ level after first differencing. This is common of macroeconomic data however. Having established the order of integration of the variables the next step will be to check for their long-run association. This is reported in table 4.3 and table 4.4.

\section{Panel Cointegration Tests}

Panel cointegration was carried out based on the Kao test and the Pedron test. The results from these two tests are reported in table 4.3 and 4.4. Table 4.3 indicates that the ADF statistic is significant at 0.05 level of significance, this in a way suggests that the null hypothesis of no cointegration can be rejected. This in a way suggest that there exists a long-term relationship between Gross domestic savings, GDP, interest rate, inflation, Domestic credit to the private sector, M2/GDP, FDI, Cross boarder bank flows and the Dependency ratio.

Table 4.3. Kao Cointegration Test results

\begin{tabular}{lcc}
\hline & $\boldsymbol{t}$-statistic & P-value \\
\hline ADF & $-2.72806^{* *}$ & 0.043 \\
Residual variance & 0.00780 & \\
HAC variance & 0.00083 & \\
\hline
\end{tabular}

Notes:

(4) Null hypothesis: No cointegration

(5) The lags used were automatically selected based on the Newey-West bandwidth using Bartlett kernel

(6) The null hypothesis of no cointegration is tested. *,**,*** indicates the parameters that are significant at $10 \%, 5 \%$, $1 \%$ probability respectively.

Source: Author's calculations

The Pedron cointegration test was carried out as a robust check. The results are reported in table 4.4.

Table 4.4. Pedron Cointegration Tests Results

\begin{tabular}{lcc}
\hline \multicolumn{1}{c}{ Tests } & Standardized Statistics & P-values \\
\hline & Pedron (1999) & 0.7685 \\
Panel v statistic & -0.734059 & 0.2490 \\
Panel p statistic & -0.677620 & $0.0242^{* *}$ \\
Panel pp statistic & -1.973654 & $0.0006^{* * *}$ \\
Panel adf statistic & -3.227043 & 0.7263 \\
Group p statistic & 0.601690 & $0.0156^{* * *}$ \\
Group pp statistic & -2.154682 & $0.0007^{* * *}$ \\
Group adf statistic & -3.175499 & \\
\hline
\end{tabular}

Notes:

(1) Panel $\mathrm{v}$ is non-parametric variance ratio statistic. Panel $\mathrm{p}$ and panel $\mathrm{pp}$ are analogous to the non-parametric Phillips-Perron $p$ and $t$-statistic, respectively. Panel adf is a parametric statistic based on the augmented Dickey-Fuller ADF statistic. Group $\mathrm{p}$ is analogous to the Phillips-Perron $p$ statistic. Group pp and group adf are analogous to the Phillips-Perron t-statistic and the augmented Dickey-Fuller ADF statistic, respectively.

(2) The formulae for calculating these statistics can be found in Pedron (1999), Table A1.

(3) The null hypothesis of no cointegration is tested. *,**,*** indicates the parameters that are significant at $10 \%, 5 \%, 1 \%$ probability respectively.

Source: Author's calculations 
The results from the Pedron cointegration test suggest that only four tests of Pedron (1999), the Panel pp statistic, Panel adf statistic, the Group pp statistic and the Group adf statistic reject the null hypothesis of no cointegration with 5\% significance level. Of these four, Pedron's (2004) simulations suggest that the Group pp statistic and the Panel pp statistic are the most powerful, given the sample size utilised in the study. Pedron (2004) state that for panel data with the number of cross sections which are nearly 20 , and the number of time units being about 30, the empirical powers of panel and group t-statistics are roughly twice as large as the other test statistics. Given that the sample utilised in the study is about 15 countries and 30 time units, this suggest that the results are robust.

Having established the presence of cointegration, the next step is to estimate the long-run cointegrating vector. The study utilised the Dynamic Ordinary Least Square (DOLS) methodology. The results are reported in table 4.5 .

Table 4.5. Dynamic Ordinary Least Squares (DOLS) Results for SADC Countries, $1980-2009$

\begin{tabular}{lccccc}
\hline \multicolumn{1}{c}{ Variable } & $\mathbf{1}$ & $\mathbf{2}$ & $\mathbf{3}$ & $\mathbf{4}$ & $\mathbf{5}$ \\
\hline GDP & $0.5685^{* *}$ & $0.6183^{* *}$ & $0.7251^{* *}$ & $0.7541^{* * *}$ & $0.6118^{* *}$ \\
INTEREST & -0.0405 & -0.0309 & -0.0954 & -0.0905 & -0.0120 \\
INFLATION & 0.0003 & 0.0001 & 0.0005 & 0.0004 & 0.0002 \\
DCP & $0.1463^{* *}$ & $0.1606^{* * *}$ & $0.0888^{*}$ & & $0.0317^{*}$ \\
M $_{2}$ /GDP & $0.2877^{* *}$ & $0.2958^{* * *}$ & $0.3141^{* *}$ & $0.1852^{* *}$ & $0.4873^{* *}$ \\
FDI & $0.4694^{* *}$ & $0.4887^{* * *}$ & & $0.4358^{* * *}$ & $0.0346^{*}$ \\
CBB & $0.0394^{*}$ & & $0.1085^{*}$ & $0.0788^{*}$ & $-4.0882^{* *}$ \\
DR & $-5.7206^{* * *}$ & $-5.8186^{* * *}$ & $-6.2536^{* *}$ & $-5.3991^{* * *}$ & 0.58 \\
R $^{2}$ & 0.79 & 0.66 & 0.65 & 0.56 & 0.53 \\
Adjusted R & 0.72 & 0.60 & 0.61 & 0.50 & 442 \\
Observations & 442 & 442 & 442 & 442 & \\
\hline
\end{tabular}

Notes:

(1) Dependent variable : Gross Savings as a percentage of GDP

(2) The DOLS was estimated including two lags and one lead

(3) All regressions include a constant not reported.

(4) $*, * *, * *$ denotes significance at the $10 \%, 5 \%$ and $1 \%$ level.

Source: Author's calculations

As indicated in the long-run equation, the magnitude of the coefficient of income is very high and significant. The coefficient is above $56 \%$ in all estimations. These results are consistent with the a priori expectations and corroborate the findings of Loayza et al. (2001) in cross-country studies, Ang (2009) in the case of India and China, and Ang (2010) for Malaysia. This suggests that the level of Gross savings in the SADC region grows with an increase in income. There is therefore a need to pursue growth-enhancing policies which are likely to result in higher productivity, hence increasing overall growth, contributing to higher savings in the SADC region.

The interest rate coefficient is negative though insignificant. This corresponds to the income effect dominating the substitution effect hypothesis and this is supported by the findings of Odhiambo (2006) and Simleit et al. (2011), but is in contradiction to the Keynesian theory. This shows that the majority of people in the SADC region are net borrowers. Therefore, an increase in the interest rate is likely to cause the income effect to dominate the substitution effect, resulting in a fall in savings. This can be accentuated by the stable financial systems in many of the SADC which offers more credit to the people.

Inflation rate which is used as a proxy for macroeconomic instability has a positive, though insignificant effect. This result is supported by Loay, Schmidt and Seven (2000). This result is also consistent with the precautionary motive, suggesting that increased macroeconomic uncertainty induces people to save a larger proportion of their incomes. This is true in part given that in a developing region or country income prospects are uncertain as compared to developed countries. In addition, the result implies that lower inflation raises growth which in turn increases savings in the SADC region. This in part implies that the character of the macroeconomic environment does not have an impact on savings in the SADC region.

The two measures of financial development are all positively related with savings. This suggests that financial deepening has played a beneficial role in the accumulation of savings in the SADC region. These results 
are consistent with the a priori expectations and correspond to the findings of Ozcan et al. (2003), Odhiambo (2006), Kelly and Mavrotas (2008), and Ogwumike and Ofoegbu (2012). Of the two indicators examined in this study, M2 as a percentage of GDP is found to be most significant. The findings are consistent with the view that savings increase with the availability of risk-sharing financial instruments as well as an improvement in the financial system. This implies that authorities should pursue policies aimed at developing the financial system as well as expanding the access of it to the general masses since it facilitates the mobilization of savings. This also points to the confidence that people have on the financial system, given that the majority of countries in the SADC region did not experience financial crises.

The results from external finance, FDI and CBB indicates that the variables are positive and significant. These findings are consistent with the notion that foreign financial flows contribute positively to savings in the SADC region. These results corroborate the findings of Hussein and Thirlwall (1999) and Baharumushah and Thanoon (2002). These results also support the Harold Domar model that foreign capital bridges the gap between domestic demand and domestic supply of finance. Given that the countries in the SADC region on average do not have sufficient savings, foreign capital plays a pivotal role in supporting growth in these countries. Therefore policies which are aimed at encouraging more foreign capital should be pursued.

The empirical results also provide support for the view that demographic factors play a role in determining the level of savings in the SADC region. This is consistent with the LCM theory discussed. The magnitude of the age in all estimations is very high and significant, which suggests that SADC's demographic transition has contributed significantly to the decrease in savings in the region given that they move in the opposite direction.

\section{SUMMARY AND CONCLUSION OF THE STUDY}

The study focused on analysing the determinants of savings in the SADC region focusing mostly on the role which foreign capital plays given that there are different views regarding its impact on domestic savings. Having reviewed a number of theoretical and empirical literature, the study adopted the permanent income/ life cycle hypothesis to analyse the determinants of savings in the SADC region. The study utilised two panel cointegration tests, the Kao test and the Pedron test. This was due to data limitations given that the Fisher test requires a longer data period. Having determined the time series properties of the data, the cointegration tests indicated that the variables of interests are cointegrated. The DOLS was further estimated to analyse the long-run relationship between the variables. The results indicated that income as measured by GDP, Foreign finance, proxied by FDI and Cross Border bank flows and financial sector variables as represented by Domestic credit to the private sector and M2 and a percentage of GDP are significant variables that explain the variation in Gross savings in the SADC region. At the same time, the rate of interest and inflation were found to be insignificant, though carrying the correct signs. The results suggests that the greater population in the SADC region are net borrowers. Thus with an increase in interest rates, people save less. However the effect is not that pronounced. At the same time the results suggest that macroeconomic imbalances have a less effect on savings as represented by the inflation variable. The results also suggested that financial sector development is of great importance in the region to promote the mobilization of savings. Also, the results provides support for the advocation of foreign capital as it complements domestic finance and hence investment activity. Demographic factors have also featured as a very important variable that determine savings in the SADC region.

\section{ACKNOWLEDGEMENTS}

The authors acknowledge the funding received from the National Research Foundation South Africa towards this project.

\section{AUTHOR INFORMATION}

Forget Mingiri Kapingura is a $\mathrm{PhD}$ (Economics) student and a Lecturer in Economics. His main area of research is on sources of finance and economic growth in Africa. He also has interest in stock market development, monetary economics, international banking and finance and investments. 
Sylvanus Ikhide is a Professor in Economics and the Head of the PhD programme in Development Finance at the University of Stellenbosch Business School. His areas of specialization are Money, Banking and Finance, Poverty Studies, Development Finance (Perspectives in Africa).

Asrat Tsegaye holds a doctorate in economics from the University of Kent at Canterbury. He has lectured and researched in several countries in Africa, including Zimbabwe, Botswana, and currently in South Africa. He is a member of the Academic Committee of the Economic Research Southern Africa (ERSA). His research interests include: Financial markets and policies; Poverty and inequality and Public finance and development.

\section{REFERENCES}

Adenutsi, D.E. (2010). Financial development, bank savings mobilisation and economic performance in Ghana: Evidence from a multivariate structural VAR. International Journal of Development Research and Quantitative Techniques 2(1):3-24.

Ahmad M.H. and Ahmed Q.M (2002), Foreign capital inflows and domestic savings in Pakistan: cointegration techniques and error correction modelling. The Pakistan Development Review 41:4 Part II, 825-836.

Ang, J.B. (2008). Are Financial Sector Policies Effective in Deepening the Malaysian Financial System? Contemporary Economic Policy, 62:623-635.

Asteriou, D. and Hall, S.G. 2007. Applied Econometrics: A modern approach using Eviews and Microfit (revised edition). Palgrave Macmillan.

Baltagi, BH and Kao, C (2000). Nonstationary Panels, Cointegration in Panels and Dynamic Panels: A Survey, Center for Policy Research Working Papers 16, Center for Policy Research, Maxwell School, Syracuse University.

Bandiera, O., G. Caprio, Jr. P. Honohan, F. Schiantarelli. 1999. Does Financial Reform Raise or Reduce Saving?" Review of Economics and Statistics 82(2): 239-263.

Bayoumi, T. 1993. Financial Deregulation and Household Saving. Economic Journal, 103: 1432-1443.

Bosede, V. K (2013) Savings and Its Determinants in West Africa Countries, Journal of Economics and Sustainable Development, Vol.4, No.18, $107-119$.

Bosworth, B. and Collins, S. (1999) Capital flows to developing economies: implications for saving and investment, Brookings Papers on Economic Activity. Vol 1, pp143-169.

Chowdhury, A.R. (2001). The Impact of Financial Reform on Private savings in Bangladesh. United Nations University, World Institute for Development Economic Research, Discussion Paper No. 2001/78.

Delwar H. (2012), Differential impacts of foreign capital and remittance inflows on the domestic saving in the developing countries : a dynamic heterogeneous panel analysis

Hawdon, D and Ahmed, A (1997) Establishing the demand for Energy in Jordan: A Stock and Watson Dynamic OLS Approach, University of Surrey.

Im, K., M.H. Pesaran, and Y. Shin (2002), "Testing for Unit Roots in Heterogeneous Panels," Journal of Econometrics, 115, 53-74.

Jappelli, T. \& Pagan, M. 1994. Savings, growth and poverty: how close are the links? World Bank Research Working Paper, No. 3203.

Kelly, R and Mavrotas, G (2008) savings and financial sector development: panel cointegration evidence from Africa, The European Journal of Finance, 14:7, 563 - 581.

Koskela, E Loikkanen, H A. \& Viren, M, 1992. "House prices, household saving and financial market liberalization in Finland," European Economic Review, Elsevier, vol. 36(2-3), pages 549-558, April.

Levin, A., C. Lin, and C. Chu (2002), Unit Root Tests in Panel Data: Asymptotic and Finite Sample Properties, Journal of Econometrics, 108, 1-24.

Loayza, N., Schmidt-Hebbel, K. \& L. Servén L. 2000. What Drives Private Saving across the World? Review of Economics and Statistics, 82:165-181.

Luüs, C. (2007). Household saving behaviour and its promotion in South Africa, Absa Group Economic Research, [On line], Available on < http://www.financialmarketsjournal.co.za/5thedition/householdsaving.htm>, Accessed on 10 August 2013.

Maddala G.S and Shaowen Wu (1999) A comparative study of unit root tests with panel data and new simple test , Oxford Bullertin of Economics and Statistics, Special Issue, 
Nwachukwu, T.E. and Odigie, P. (2009). What drives Private savings in Nigeria? A Paper presented at the Centre for the study of African Economies Conference, University of Oxford, March.

Odhiambo, N.M. (2008). Interest rate reforms, financial depth and savings in Tanzania: A dynamic linkage. Savings and Development, 32(2):141-158.

Okafor, L. M. (2010). Saving less when there is more? Foreign debt and savings in developing countries. Journal of economic policy reform, 13(3), 213-223.

Pedroni, P. (1999), "Critical Values for Cointegration Tests in Heterogeneous Panels with Multiple Regressors," Oxford Bulletin of Economics and Statistics, 61, 653-670. (2000), "Fully Modified OLS for Heterogeneous Cointegrated Panels," Advances in Econometrics, 15, 93-130, 631-652.

Quartey, P. (2005). Financial Sector Development, Savings Mobilization and Poverty reduction in Ghana. UNU World Institute for Development Economics Research (UNU-WISER).

Reinhart, C.M. \& I. Takatlidis. 2001. Before and After Financial Liberalization, [On line], Available at: $<$ http://www.puaf.umd.edu/faculty/papers/reinhart/FINLIB.pdf>. Accessed: 20 May, 2007.

Sahoo, P. \& Dash, R.K. 2013. Financial Sector Development and Domestic Savings in South Asia. Economic Modelling, 33:388-397.

Shaheen, S., Maryam, F and Javed, F. (2013). Impact of foreign capital inflows on domestic saving of Pakistan. Institute of Interdisciplinary Business Research, 4(10), 2013, 443-457.

South African Savings Institute. (2001). Savings Review October 2001 Vol 1, [On line], Available on $<$ http// www.csae.ox.ac.uk/resprogs/smmsae/pdfs/smmsae-2001-075.pdf $>$ Accessed on 10 July 2014.

Temitepo L.A.L. (2014) The effects of foreign resources inflow and savings on the economics growth of South Africa: A VAR. Journal of economics \& Behavioral studies Vol 6 No.3.pp 232-241.

Waheed A, (2002) Foreign capital inflow and economic growth of developing countries. A critical survey of selected empirical studies. Journal of economic corporation. Vol 4 (1), 1-36.

Yaya, K (2011) Long-run Determinants of Savings rates in WAEMU Countries: An Empirical Assessment From ARDL Bounds Testing Apptoach, South African Journal of Economics, Vol.79.3, pp $312-329$. 


\section{NOTES}

